\title{
ЧУЖДОТО БОГОМИЛСТВО? ИСТОРИОСОФСКИТЕ КОЛЕБАНИЯ НА ПЕТЬР МУТАФЧИЕВ
}

\author{
GeORgi MinczeW \\ University of Lodz
}

\begin{abstract}
FOREIGN BOGOMILISM? THE HISTORIOSOPHIC HESITATIONS OF PETAR MUTAFCHIEV. The article is dedicated to the 1934 philosophical and historical essay by Petar Mutafchiev entitled The Priest Bogomil and St. John of Rila. The Spirit of Negation in Our History (Поп Богомил и Свети Иван Рилски. Духът на отрицанието в нашата история), discussed in the context of both the author's general historiographic output and the spiritual and cultural explorations of Bulgarian intellectuals in the interwar period. The study examines certain external influences on Mutafchiev's scholarly work, first and foremost Benedetto Croce's views on absolute historicism. It also investigates three central historiosophic concepts of the Bulgarian medievalist: 2) the saltatory development of Bulgarian history, 2) the destructive impact of Byzantinism on the political, religious and cultural life of medieval Bulgaria, as well as 3 ) the superficial character of the Bulgarian people's religion - the effect of receiving foreign Christianity from the very same Byzantine hands. In this regard, Bogomilism appears to be an external doctrine, having incorporated older dualist ideas, which passed through Byzantium and therefore also reflected the destructive Byzantinism to some extent. Mutafchiev's original concept deviates from earlier views and testimonies, attesting to the excellency of both the essay itself and the historian's overall vision of Bulgarian history.
\end{abstract}

Keywords: Petar Mutafchiev, Bogomilism, Bulgarian interwar historiography

Миналото се инструментализира във всяка следваща епоха. Или казано другояче: нагоденото към актуални политически и идеологически модели минало изгражда национална идентичност. Особено там, където формирането на идентичността е исторически закъсняло спрямо други по-близки или по-далечни държави. Например на Балканите. Митовете за забравеното славно минало, за великите царе или за страданията на героичния народ под чуждо иго се превръщат в топоси още в първите

1 This article has been written under the research project financed by the National Science Centre (Poland). Decision number: DEC-2016/22/M/HS3/oo212 (Dualist Heresies in the History of South-East Europe, $9^{\text {th }}-15^{\text {th }}$ century). 
историографски опити на сърби и българи: в бароковите сръбски исторически съчинения ${ }^{1}$ или в История славянобългарска на отец Паисий Хилендарски. И независимо че от XIX в. насам различни исторически школи се опитват да демитологизират предходното време и да интерпретират обективно сигурни факти, зад всеки научен текст стои конкретен човек, съвременен интерпретатор, който не може да избяга от своето време и дори само с избора на полето на изследване вече пренася, съзнателно или несъзнателно, миналото в съвременността, а с него - и създадените по-рано топоси, реинтерпретирани в съгласие с определена ментална нагласа и от позицията на съвременен за автора идеологически и/или политически модел.

Богомилският мит и неговите трансформации заемат особено място в българската литература, в теософски и псевдофилософски писания. Много добър анализ на голяма част от тези текстове предлага монографията на Гражина Шват-Гълъбова². Задачата на тази статия е малко по-различна: тя е опит да се проследят проекциите на богомилския мит в междувоенната научна литература и въпреки че анализът на философски текстове и научни монографии често води до някои сходни изводи от посоченото изследване на Шват-Гълъбова, той предполага по-различна методология.

Есето на Петър Мутафчиев (1883-1943) Поп Богомил и Свети Иван Рилски. Духът на отрицанието в нашата историяз заема особено място сред гласовете за и против богомилството в българския научен дискурс. Според мен този текст би трябвало да се разглежда във връзка с едно негово по-ранно есе, посветена на византинизма ${ }^{4}$, както и с някои академични трудове на автора: встъпителната лекция в Софийския университет през 1923 г. $^{5}$, История на българския народ ${ }^{6}$, Книга за българитет. Струва ми се също така, че посланието на есето не може да бъде разбрано извън атмосферата на духовните търсения на нашата интелигенция между двете световни войни.

1 Напр. издадената във Виена през 1794-1795 г. История разных славенских народов найпаче болгар, хорватов и сербов на Йован Раич.

2 Haeresis bulgarica w bułgarskiej świadomości kulturowej XIX i XX wieku (Szwat-Gylybowa 2010).

3 Публикувано във Философски преглед (Mutafchiev 1934: 1-16).

4 Към философията на българската история. Византинизмът в средновековна България, публикувано също във Философски преглед (Mutafchiev 1931: 27-36).

5 Изток и Запад в европейското средновековие (Годишник на СУ, ИФФ, т. ХХІ, кн. 2, 1925, с. 1-34). Цитатите от двете есета и академичната статия са по Mutafchiev 1993: 159-168, 169-184, 127-158.

6 Т. 1-2, София, 1943; цит. по 2. изд. (под научната ред. на проф. В. Гюзелев): Mutafchiev 1986. За богомилството в І Българско царство вж. с. 208-216; за богомилството по време на византийското владичество - с. $250-251$.

7 Mutafchiev 1987. 
П. Мутафчиев без съмнение е един от най-оригиналните български медиевисти. Противопоставил се на позитивистичната традиция в изследвания на учени като Васил Златарски и Петър Ников, той търси в обобщения от историко-философски и културно-философски характер причините за някои процеси в средновековната ни история, обяснени с народопсихологията на българите и с влиянията на чужди религиозно-политически модели върху средновековното ни минало ${ }^{1}$. За формирането на светогледа на П. Мутафчиев решаващо значение изиграва специализацията му в Германия (1920-1922) при мюнхенския византинист и редактор на Byzantinische Zeitschrift Август Хайзенберг, представител на немската културно-историческа школа, или по-скоро на филологично-историческата школа, съчетаваща конкретния текстологичен труд при издаването на византийски паметници с изводи от културно-историческо естество. Струва ми се пресилено твърдението на Васил Гюзелев, че принадлежността на П. Мутафчиев към социалистическата партия и основното му запознаване с Марксовото учение на младини оставят значителни следи в метода му на изследване и мислене 2 . В съчиненията му наистина личат някакви остатъци от прогресивни възгледи, напр. за пропастта между власт и народ и особено за реакционната роля на Православната църква в българската история - възгледи, които ще бъдат атакувани в по-ново време - от православните отрицатели на богомилството, но и от апологетите на ереста. Ако трябва обаче да се търсят действителни философски влияния в творчеството на П. Мутафчиев, те идват от някои антипозитивистични концепции за историята на Хегел и най-вече - на неохегелианската идея на Бенедето Кроче за абсолютния историзъм, според която философията е философия на духа, а от своя страна философията на духа е мислене, съдържащо в себе си историята. Този философски историзъм, разбиран като познание на действителността и най-вече на културните и социални явления в историческото им развитие, е бил близък на П. Мутафчиев: в трудовете му философските теории се съчетават с култивираното в Мюнхен прецизно изследване на изворите, което превръща изследванията му в амалгама от оригинални идеи и коментиран през тяхната призма исторически материал. Тук ми се иска да цитирам още веднъж

1 Сред излезлите през последните години публикации, посветени на научното творчество на П. Мутафчиев, заслужава да се отбележи книгата на К. Пампов Философия на средновековната българска история. Гледната точка на проф. Петър Мутафчиев (Ратроv 2013) - един добър опит за представяне на трудовете на българския медиевист през призмата на философско-историческите концепции на чужди и наши автори и школи: Хегел, Б. Кроче, мюнхенската културно-историческа школа, П. Бицилли и др.

2 В предговора към Книга за българите (Gyuzelev 1987: 16-17). 
В. Гюзелев и в този случай частично да се съглася с него: Тя (Книга за българите - Г. М.) отразява идейната криза в българското общество между двете световни войни, постепенното рушене на вярата и доверието в историческия позитивизъм u обективизъм ${ }^{1}$. И да допълня: идейната криза и недоверието към позитивизма и обективизма са характерни не само за българското общество - кризата е общоевропейска, а някои от спорните и днес концепции на автора, особено за мястото на еретическите учения в тъканта на средновековното общество и за ретроградността на Православната църква, се вписват в интелектуалната атмосфера в България по онова време, характеризираща се с антирелигиозен, антиклерикален и особено антиправославен патос на по-голямата част от българската интелигенция.

Антирелигиозна в средите на ляво ориентираната ѝ част, повтаряща марксистките клишета за религията като опиум за народа и за Църквата като реакционна идеологическа структура - крепител на феодалното общество, социал-марксистката интерпретация на богомилската ерес в България съпровожда прохождането на социалистическото движение у нас, а първият застъпник на хетеродоксите от позициите на историческия и диалектически материализъм (че и от позициите на политическата икономия на капитализма) е Димитър Благоев. В своята брошура за историята на социализма в България той задава матрицата на марксисткото тълкуване на ереста като обществен, но стихиен процес с християнско-комунистически аспирации; а той бил стихиен и християнско-комунистически, тъй като:

В средните векове господстваше натуралното стопанство, произвеждането главно за потребяване; размяната, търговията беше неразвита. При такива условия човешкото съзнание не можеше да се издигне по-високо от идеала на първобитното християнство ${ }^{2}$.

Четирите посветени на богомилството страници в брошурата ще се превърнат във верую на следващите поколения марксисти: в междувоенния период идеите на Д. Благоев са развити напр. в книгата на левия сектант Иван Клинчаров (1877-1942) Поп Богомил и неговото време посмъртно - на V конгрес на БКП през 1948 г. Добре образован юрист (докторат по право в Лион) и убеден марксист, съмишленик на тесните социалисти, след 1923 г. той отказва да се подчини на коминтерновския диктат за болшевизация на БКП и през 1927 г. е изключен от Работническата партия (к.). Парадокс е, че книгата на

1 Gyuzelev 1987: 17.

2 Blagoev 1906: 7, 9.

3 1. изд.: 1927; цит. по 3. изд: Klincharov 2019. 
един от най-верните продължители на материалистическите утопии на Д. Благоев е забранена в комунистическа България, вместо да бъде включена в хора от гласове, възхваляващи класовия характер на богомилското движение. А И. Клинчаров би бил много полезен, особено с идеите си за политическата програма на богомилите. Според автора тя била в пълно съгласие с тяхното социално мировъзрение и се изчерпвала с две неща: 1. Възстановяване на дребната земеделска собственост, която по насилствен начин бе изтръгната от ръцете на селското население... 2. За да бъде осъществена тази програма на практика, богомилите се стремяха да завладеят политическата власт по пътя на политическото съглашение, бунта и общото народно въстание (Klincharov 2019: 144).

Кога богомилите са се опитвали да завладеят политическата власт и да вдигнат общонародно въстание? Авторът приписва на еретиците откъслечни вести за селски бунтове, бърка павликяни с богомили и никак не е прецизен в използването на извори и научна литература. Авторът се е забързал да докаже интернационалния комунизъм на богомилското движение, в бързината цитира изборно и демонстрира слабо познаване на изворовия материал и коментиращата го научна литература, а прави и много фактологични грешки, които редакторът на третото издание на книгата се е почувствал задължен да поправи под линия ${ }^{1}$.

Но фактите нямат значение, важно е внушението: еретиците са имали нещо като Манифест на богомилската партия, а общото народно въстание ще даде политическата власт в ръцете на отрудените селски маси. По комунистическо време социал-марксистките фантазии на Д. Благоев и неговите последователи вече се превръщат в догма: отклоненията от класовото тълкуване на богомилството се изобличават като реакционни, националистически, фашистки. Догма, от която посмъртно ще пострада и П. Мутафчиев.

Антиклерикален и антиправославен е патосът сред онази част от българската интелигенция, която преживява мъчително разочарованията на националните катастрофи и търси реализация на духовните си тежнения в модерните за-

1 Ето само няколко примера: на с. 29 Синодика на цјар Борил (наречен от автора Синодик на Борис) е датиран 1210 г. (поправено под линия на 1211); пълно е объркването на автора в описанието на еретически учения, които според него послужили за образци на богомилските науки: според И. Клинчаров монофизитството и монотелитството възникват през III в., а не съответно през V и VII в. Тези постари, според автора, учения повлияли на по-късните манихейство и павликянство. Анахронизми, поправени в ред. бел. на с. 45; цар Иван Владислав и жена му били богомили (коригирано с ред. бел. на с. 82: Това предположение се основава на несигурни данни.); монахът мистик Константин Хризомал, чиито съчинени публично били изгорени в Константинопол през 1140 г., е обявен за богомил (поправено в ред. бел. на с. 87). 
падноевропейски, декадентски в същността си, философски школи и религиозни движения. Повърхностното усвояване на чуждото води и до парадокс - ражда компенсаторно възхваляване на родното: родната земя, народ, величието на старата ни история ${ }^{1}$. Достатъчно е да се прелистят страниците на български списания от 20-те и 30-те години на XX в., за да се проследят и двете тенденции. Публикуват се статии на европейски теософи, адепти на източни учения, свободни християни и откровени мошеници. В съседство са отпечатани разсъждения за българския дух, величието на българската раса и необходимостта българската култура да се въздигне до висотите на европейската, внасяйки в нейната съкровищница най-ценното от родната духовност. Ако потърсим общото в този религиозен миш-маш, ще го намерим в отричането на Църквата като институция, и най-вече на Православната църква, която била лишена от метафизичен дух, не изпълнявала пастирските си задължения, а в храмовете вместо песнопения се чували неразбираеми крясъци². Вина за отрицанието на православието може да се потърси и в самата българска Църква, която не създава толкова търсеното от интелигенцията богословие с метафизически дух. Но нека не забравяме, че в междувоенния период тя, Църквата, продължава да е схизматична: непризнавана от останалите православни канонични общности, има сериозни трудности в общуването с чужди богословски факултети и православни интелектуални кръгове. Йерарсите често продължават образованието си в католически или протестантски университети. Екзарх Стефан напр. защитава през 1919 г. докторат във Фрибург (Швейцария) на тема именно за богомилствотоз. Публикациите на духовници и свързани с църковните среди учени са предимно в областта на църковната история и защитават налаганата още от епохата на Възраждането идея за Църквата като защитница на народността в кризисни исторически периоди: византийско владичество, турско робство.

1 Не искам да влизам в полемика нито с разсъжденията на А. Кьосев за само-колонизиращите се култури, нито със студията на И. Еленков за родното и дясното в българската култура между двете войни (вж.: Kiossev 1999, Elenkov 1998). Някои от плодотворните идеи на посочените автори биха могли да се приложат и към описваната тук ситуация, но тъй като религиозното светоусещане не е основна тема и на двете изследвания, съгласията и възраженията биха заели много място и биха отклонили този конкретен текст от заложената в заглавието тематика.

2 Вж. ценните наблюдения на К. Рикев в монографията му върху А. Далчев (Rikev 202о: раздел Религиозната проблематика в „Изток“ и „Стрелец“).

3 Богомилите и Презвитер Козма (Stefan 2012). Докторската теза на екзарх Стефан, защитена през 1919 г. на френски, не внася съществено нови идеи в проучването на богомилската ерес. Текстът е интересен по-скоро като позиция на Църквата към дуалистическото учение. 
Естествено е противниците на институционалната Църква да потърсят вдъхновение в движения, отричащи официалните религии. И го намират напр. в богомилството, което било ...дало квас на иялото възраждане на нашия континент, а славянската раса с българите сред нея - като призвана в бъдеще да реализира Сърцето и разсъдъчния гений на Ума‥ Месианистичните нотки в цитираната статия са обосновани от презумпцията, че след като българските богомили са предвъзхитили Ренесанса, то същите българи като част от славянската раса са призвани да донесат новото рационалистическо възраждане на Европа. Авторът най-вероятно е повлиян от чужди историци, обърнали внимание на българската история именно във връзка с разпространението на дуалистически учения от Балканите към Западна Европа и потърсили в съпротивата срещу официалната (в случая Католическа) църква предренесансови, а дори ренесансови елементи ${ }^{2}$. Вестникарските съчинителства ще заживеят отново в псевдонаучната публицистика от 70-те и 8о-те години на XX в., когато към наложените върху богомилството вулгарно-марксистки щампи ще се прибави националистичен повей, раздухан от формирания около Людмила Живкова кръг от учени и културни функционери ${ }^{3}$.

$$
* * *
$$

Текстът Поп Богомил и Свети Иван Рилски би трябвало да се разглежда като плод и едновременно с това съпротива на споменатата атмосфера. Жанрът на творбата не предполага конкретен анализ на факти, философското есе представя абстрактни крайни тези, защитавани от автора в духа на философския историзъм. Внимателният прочит обаче открива зад обобщенията едно добро познаване на известния за онова време фактологичен материал и интерпретацията му съгласно наложения вече холистичен мит за богомилството като единно дуалистическо учение, разпространено от малоазийските провинции на Византия, през Балканите до Южна Франция.

1 Статията на К. Кръстев Възможностите за една българска култура (Krastev 1927: 1).

2 Всъщност идеите за предренесансов еретически протест срещу официалната Църква би трябвало да се прецизират. Първите изследователи на ереста през XVIII в. (G. Arnold, C. J. Wolf и J. L. Oeder) са свързани с протестантската богословска традиция, виждаща в богомилите свои предшественици, тъй като отричането на Католическата църква слага началото на Реформацията. Но тогава богомилите биха били предходници на Реформацията, а не на Ренесанса.

3 Вж, напр. книгата на В. Топенчаров Две жарави. Един пламък. Бугри и катари: Защо първата общоевропейска народна вълна против феодализма бе наречена „българска ерес“ (Topencharov 1974). 
П. Мутафчиев е професионален историк и внимателно борави с изворите, за разлика от повечето от споменатите по-горе текстове, където се подхвърлят необосновани догадки, а често и известните факти не се познават достатъчно добре или съзнателно се преиначават.

Поп Богомил и Свети Иван Рилски няма нищо общо с междувоенната публицистика и съчинения, претендиращи за научен прочит на ереста. П. Мутафчиев не противопоставя, а приравнява тези две емблематични за българската историческа памет личности, доколкото поп Богомил е бил действителна личност, а не обобщен, имагинерен образ на ереста. Общото между тях авторът търси в интерпретацията на наложеното със сила християнство в едно общество, не надживяло по естествен път старите езически вярвания. Християнството е наложено отгоре; то не е естествен процес на заменяне на една изпаднала в криза религия с друга, а е държавен акт:

\begin{abstract}
Новата религия, следователно, не се яви за нас като изход от дълбока духовна криза. Поради това и приемането ѝ не можеше да се извърши като естествен процес. Отказът от старите вярвания бе обусловен от съображения на върховната държавна власт, от мотиви, значи, лежащи извън сферата на общото религиозно съзнание и недостъпни за разбиранията на масите. Това именно обяснява факта, гдето християнството трябваше да бъде наложено чрез принуда. (Mutafchiev 1993: 171)
\end{abstract}

И тук П. Мутафчиев включва в разказа любимата си идея за византинизма като зло за България, а по-точно: зло както за държавността, така и за народните маси. Византийската имперска традиция е враждебна към отделните народности заради своя унифициращ потенциал, твърди авторът още във встъпителната лекция от 1923 г. Византийското православие пък пренесло по нашите земи образци от чужда култура, разбираеми за една тънка прослойка от обществото, но непонятни за масите със своята тържествена, но пуста обредност и ритуал, чиито служители останаха чужди на дълга на мисионерството (с. 172). Вината за това състояние е в елитите - вместо да защитават националните начала и културна обособеност, висшите духовници се превръщат в проводници на византинизма, в рушители на националния дух и държавността (с. 173).

Духовният хаос през първите векове след приемането на новата религия, съжителството на неизживени езически елементи с повърхностно усвоено християнство било довело до едно неверие и духовен анархизъм, характерни за българската народопсихология от Средновековието до съвременността.

В атмосферата на духовна неразбория и плитка християнска религиозност се ражда богомилството. За П. Мутафчиев то не е християнска секта, въпреки че богомилите са се наричали християни, а по-скоро песимистична религия, заменила 
оптимистичната вяра в добрия и всеопрощаващ Бог с дуалистичната вяра в мрачния демиург, владетел на земното царство:

Срещу наивния, преизпълнен с възторжена радост, упование и светлина мироглед на древния християнин, който виждаше своя всемогъщ и благ Бог във всяка частица на мирозданието, богомилството с вярата си в творческата сила на Злото, представяше същинска религия на отчаянието. (Mutafchiev 1993: 174)

Нашият медиевист вижда причините за появата и разпространението на богомилството отново във византинизма като наложен външен религиозен и културен модел: на проповядваната от устроената по византийски образец официална Църква невнятна за масите догматика и богослужение богомилските проповедници противопоставяли простите, но вразумителни учения на източните секти ${ }^{1}$. Неправилно е обаче да се смята, че авторът е апологет на дуалистичната ерес, напротив: за него богомилството е крайно антисоциална доктрина. Отхвърляйки всичко земно като творение на Сатаната, то всъщност се проявява като мрачна обществена философия на пълното отрицание ${ }^{2}$. Поради тази причина е неправилно да се смята, че еретиците били реформатори на Църквата или обществото - те са негови рушители и неслучайно общините им изживявали разцвет в исторически периоди на криза на държавността: в заника на I и II Българско царство, в Босна преди османското нашествие и в Южна Франция по време на кръстоносния поход срещу катарите в началото на XIII в.

Образът на св. Иван Рилски е само привидно въведен като антитеза на поп Богомил, духовният подвиг на рилския пустиножител също е пример за вредните последствия на нахлулия в българските земи византинизъм:

Но трагизмът в старата ни история не бе само в това, гдето съзнанието на народа ни оставаше винаги разпънато между две еднакво безплодни и, от гледището на националните ни интереси, еднакво вредни крайности - богомилството, от една страна, и византинизмът - от друга ${ }^{3}$.

Православното анахоретство по византийски модел е един от пътищата за проникването на разрушителните чужди религиозни и културни модели в средновековна България. Личният духовен подвиг и простата вяра на св. Йоан са оценени високо от П. Мутафчиев, но не и социалната му активност! За пример е използван известният епизод

1 Към философията... (Mutafchiev 1993: 165).

2 Поп Богомил... (Mutafchiev 1993: 175).

3 Поп Богомил... (Mutafchiev 1993: 177). 
от т.нар. Народно житие на светеца, описващ несъстоялата се среща между цар Петър и св. Иван. Във времената на разтърсваното от политически и социални вълнения царство владетелят търси съвет от духовен авторитет. Но какво получава? Светецът:

\begin{abstract}
...скрит низ планинските пущинаци и забравил за човека, който страдаше и търсеше лек за страданията си, той съзерцаваше Бога. Тук, победен от мълвата, бе се запътил да го дири и българският цар Петър, тук трябваше да го търсят и всички тия прости и отрудени синове на нашия народ, които - измъчвани от съмнения или от чувство на духовна слабост - жадуваха за вяра, за лек срещу болките на земния си живот или за успокоение на страховете си пред тъмното народно бъдеще. Но това, което в края на своето пилигримство те можеха да отнесат със себе си, бе само споменът за бегло зърнатата фигура на светия човек или някоя отронена от него дума ${ }^{1}$.
\end{abstract}

Оказва се, че не само богомилството е причина за трагизма на българската средновековна история. Ние бяхме не само богомилски народ, но и народ на отшелници - заявява П. Мутафчиев. Неслучайно преди падането на II Българско царство страната била препълнена не само с богомили... гори и пещери гъмжеха и от подивели отшелници ${ }^{2}$

Заключението на автора е песимистично, както впрочем внушението на целия текст: Поставен в крайно неблагоприятни и тежки условия за съществуване, народът ни, повече от всеки друг народ, се нуждаеше от апостоли и от водачи -ясновидци и творци. Неговото нещастие се състоеше в това, че той винаги се виждаше воден от слепи подражатели на чуждото или от отшелници и гении на отрицанието (с. 183).

Този противоречив в посланието си текст буди възражения, съпровождащи го от публикацията през зо-те и 40-те години на XX в., през периода на комунистическата власт, та чак до наши дни. Не ми се иска да бъда пореден съдник на идеите на известния медиевист. Без да съм съгласен напълно с позицията му, ще се опитам да разгледам, доколкото се може безпристрастно, гледището му сред други противоречиви схващания за дуалистичната ерес от междувоенния период.

Вече споменах, че жанрът на творбата не предполага конкретен анализ на факти. Което не означава, че П. Мутафчиев не ги познава. Съмнява се в историчността на поп Богомил; отрича оригиналността на дуалистичната доктрина, виждайки в нея смесица от източни хетеродоксални учения, адаптирани към българските условия; загатва за разпространението на ереста в Западните Балкани и Южна Франция; независимо от отрицателното си отношение към византинизма отбелязва, че за разлика от политическото съперничество между България и Византия, дошлият от

\footnotetext{
1 Поп Богомил... (Mutafchiev 1993: 179).

2 Поп Богомил... (Mutafchiev 1993: 181).
} 
Източноримската империя религиозно-културен модел е приет естествено (друг е въпросът за оценката на византинизма като негативно, разрушително влияние върху българското общество и държава).

Това, което е скрито зад текста на есето, е развито с инструментариума на академичното историческо изследване в издадената в годината на неговата смърт История на българския народ. Тук идеите от Поп Богомил и Свети Иван Рилски са развити и обяснени не през философско-есеистичния, а през научния дискурс. Проследен е разцветът на богомилството в кризисни за държавността и обществото периоди: царуването на цар Петър, в смутните години на византийското владичество (XI- XII в.) и в началото на XIII в. Накратко е разгледана доктрината на движението, както и разпространението ѝ на Балканите и в Западна Европа. Тези редове от съчинението не са особено оригинални: авторът повтаря идеи на Йохан Дьолингер, Франьо Рачки ${ }^{1}$, Йордан Иванов ${ }^{2}$. Пресилено е твърдението за липса на връзка между българските и византийски хетеродокси, още повече, че авторът цитира труда на Герхард Фикер Die Phundagiagiten (Leipzig 1908), а спирайки се на разпространението на павликянството по българските земи, отбелязва, че тази дошла от малоазийските провинции на Източноримската империя ерес е близка на българския дуализъм и е повлияла върху неговата космогония и социална доктрина. Затова отговорът на въпроса: защо едно подобно учение не се създаде в никоя друга страна, например във Византия, а се падна нам заслугата да го дадем на света? изглежда на пръв поглед странен. Защото, отговаря П. Мутафчиев:

... в другите страни и народи развитието следваше своя естествен път, осъществяваше се бавно и постепенно... У нас бе тъкмо обратното: в разстояние на няколко десетилетия народът ни изживя онова, за което на други бяха потребни векове... и накрай - неудържимо проникване на една чужда култура, чието шествие оставяше тук само поквара или развалини ${ }^{3}$.

Отговор, странен само на пръв поглед. Твърдението е в съгласие с идеята на П. Мутафчиев за скокообразното развитие на българската история за разлика от естественото, еволюционно развитие на много европейски народи и държави (в това число и на Византия). В България, твърди той, периодите на разцвет са кратки и след няколко десетилетия са следвани от продължителни времена на упадък. Една идея, видна още

1 Bogomili i patareni (Racki 1931; ориг. изд. 1869-1870).

2 Богомилски книги и легенди (Ivanov 2019; ориг. изд. 1925).

3 История на българския народ... (Mutafchiev 1986: 215). 
във встъпителната лекция от 1923 г. и защитена в есето Към философията на българската история. Защо в българската история се забелязва странна липса на приемственост, последователност и равномерност в политическия и духовен живот на българите ${ }^{1}$ В отговор авторът изброява кратки епохи на възход и бързо последвал ги упадък: скоро след смъртта на цар Симеон България е вече глинен колос, лесна плячка на дружините на Светослав и войските на Йоан I Цимисхий; три десетилетия продължава възстановената с огромни усилия държавност при Самуил - следват почти два века византийско владичество; така е и във Второто българско царство: пет години след смъртта на Иван Асен II българската държава изгубва две трети от земите си, след което настъпва дълъг период на разложение, довел до падането на държавата под турско робство (с. 160-161). П. Мутафчиев не крие, че тази концепция не е негова, а на руския историк-славянофил от XIX в. А. Ф. Хилфердинг. Не забравя и за споменаваното вече на няколко пъти разрушително въздействие на византинизма върху религиозно-културния живот в средновековна България, който според него е една от основните причини за упадъка. Византия била първоначално чувствана от българите като представителка на една враждебна култура..., но същевременно и една враждебна политическа сила (с. 163).

Лично за мен спорни са не толкова теорията за скокообразното развитие и щетите от византинизма за нашата държавност и култура, колкото концепциите за пагубната за българското общество роля на приетото от Византия християнство. Ако се съгласим с тезата, че наложената със сила чужда религия върху неизживяното по естествен път езичество е била грешка, довела до изгубването на народностна идентичност и като последствие - до най-големите трагедии в историята ни, ще трябва да се запитаме: не е ли било така в повечето средновековни държави? Съпротива срещу християнството има не само в България по време на управлението на Владимир-Расате $^{2}$, а и в други страни: в Киевска Рус и в Полша по времето на Болеслав Храбри

1 Към философията на българската история... (Mutafchiev 1993: 160).

2 Езичеството на Владимир-Расате се е превърнало по-скоро в топос, в пореден исторически мит, обслужващ всякакви прабългарски, антихристиянски концепции за етногенезиса на българите и религиозната ситуация в средновековна България, чиито автори нямат изглежда време да прочетат някои сериозни исторически изследвания, в които управлението на Владимир-Расате се разглежда не толкова като езически преврат, а по-скоро като стремеж за еманципация от Константинопол чрез търсене на съюз с Немското кралство. Още И. Дуйчев се съмнява в достоверността на изворите и обвинява гръцките и латински хронисти в тенденциозност. Критичен преглед на съществуващата литература и коментар на изворите вж. в Iliev 2002: 407-410. И. Илиев според мен правилно отбелязва: неговата (на Расате - Г. М.) дейност ни се представя по-скоро като един неосъществил се опит за подновяване на българския политически и културен диалог с Европейския запад, започнал още по време на българското настаняване на Балканите, и продължаващ, макар и с различна интензивност, и до наши дни (с. 410). 
и неговите наследници (началото на XI в.). И в двете държави новата религия е наложена по чужд модел: византийски в Киевска Рус и немско-чешки в Полша. Двоеверието, съжителството на славянски езически вярвания с православие и католицизъм съпровождат религиозния живот на тези две страни в дълъг период от развитието им, също скокообразно, придружавано от дълбоки кризи на държавността. Примерите могат да се множат с посочването на други европейски държави, за които християнството се превръща в цивилизационен избор. Причините за плитката религиозност и неверието на българина следователно не е в чуждия модел, а в начините на усвояването му. Въпреки че и в този случай бих могъл да поспоря с автора: християнството в България може и да е проповядвало невнятни догми и да е предлагало на паството един пищен, но неразбираем ритуал. Дори така да е, проповедта и богослужението са се извършвали на разбираем език, за разлика от Западна Европа, където народните езици навлизат в богослужението едва след II Ватикански събор през втората половина на XX в.

А и какъв оригинален религиозно-културен модел е могъл да възникне в България на мястото на езическите вярвания? Имал ли е княз Борис алтернатива, или е трябвало да приеме едно от християнските вероизповедания на средновековна Европа, за да се превърне България в истинска европейска държава? Той избира, правилно според мен, източнохристиянския модел и далеч не съм убеден, че както той, така и българските владетели и йерарси след него сляпо следват византинизма. Напротив, цялата ни средновековна история е белязана от стремежа за институционална еманципация на българската Църква от Константинопол и постигане на автокефалия: единствения църковно-юридически правилен начин за налагането на народностна църква в лоното на православието. Трудно ми е да се съглася също така, че в българската Църква липсвал мисионерски дух. Та не е ли тя през Кирило-Методиевата епоха именно мисионерска? Не са ли мисионери и истински духовни будители учениците на Светите братя, посели християнството на понятен език по цялата територия на I Царство? Не се ли превръща по-късно патриарх Евтимий в неоспорван авторитет не само за българското православие, но и за цялата Slavia Orthodoxa?

Но да се върнем към богомилството като проява на духовния анархизъм и повърхностната религиозност на българина. В История на българския народ то е определено като неоригинално движение, сглоба на отделни елементи от учения, с векове nо-стари от него ${ }^{1}$ - това също е твърдение, появило се още в есето от 1934 г. Казано иначе, както византинизмът, така и богомилството е външно: едно учение, възприело по-стари дуалистични идеи, преминали именно през Византия, т.е. в известен смисъл

1 Mutafchiev 1986: 213. 
то, богомилството, също е проява на разрушителния византинизъм. Наистина П. Мутафчиев споменава, че ереста била реакция на официалната православна догматика и ритуал, които размътваха народното съзнание, откъснато от вярата на дедите (т.е. езичеството - Г. М.). Тези вярвания се срещнаха с простите, но вразумителни учения на източните секти, за да родят мирогледа на богомилството... една нова религия, която увлече масите ${ }^{1}$. Но ако приемем, струва ми се с основание, тезата за неоригиналния характер на това неоманихейско учение, ще трябва да се съгласим, че то е толкова наше, колкото и чуждо.

Непредубеденият изследовател на ереста със сигурност ще се съгласи с мнението, че богомилското учение е сглоба от по-стари хетеродоксални доктрини и следователно - има подражателен характер. Тази непредубеденост обаче липсва в България, където богомилският мит преди П. Мутафчиев и след него е обременен с идеологически тълкувания, излизащи далеч извън полето на научните търсения. Много показателни в това отношение са и редакторските бележки на В. Гюзелев към преиздадената през 1986 г. История на българския народ. Текстовете за богомилството са снабдени с разяснения, критикуващи немарксистките, вулгарно-материалистически възгледи на П. Мутафчиев от позициите на наложената след 1944 г. доктрина за богомилството като форма на класова борба на българското селячество срещу господстващия феодален строй и съдържащо оригинални елементи, които го отличават от манихейството и павликянството. А за правилно разбиране на богомилското движение на читателя се препоръчва да се обърне към каноничния за периода труд на Д. Ангелов Богомилството в България².

Схващанията на българския медиевист са критикувани и в най-ново време: православните критици на богомилското инославие се дразнят от сравняването на поп Богомил със св. Иван Рилски и виждат в есето тенденциозен текст, където Мутафчиев без подкрепата на сравнителни доводи, пренебрегвайки становището на Църквата, както и естествената народна памет, обявява доброволното отшелничество в Христа на св. Иван Рилски и насилствената обществена изолация на богомилите за

1 Към философията... (Mutafchiev 1993: 165).

2 Вж. бел. 7 и 9 на с. 210 и 215 от Историята. Редакторът цитира изданието на Богомилството в България от 1969 г. (Angelov 1969). Всъщност издателската съдба на труда на Д. Ангелов е много интересна и е обект на отделно проучване. В първото (1947 г.) и второ разширено изд. (1961 г.) изобилстват твърди марксистки формулировки по съветски образец и неслучайно първото изд. е преведено на руски през 1954 г. В класическото изд. от 1969 г. те пак присъстват, но са по-омекотени, а коментираният фактически материал е много по-обширен. През 1993 г. излиза ново издание, вече със заглавие Богомилството, опит за изчистване на възгледите на автора от марксистките клишета, които все пак надникват иззад редовете. 
едно и също социално явление ${ }^{1}$. И сигурно са донякъде прави: опитът за търсене в анахоретството на елементи на социална активност напълно противоречи на естеството му - еремитите бягат от света, те не са част от него. Невъзможно е един пустиножител да бъде едновременно и политически лидер; може да бъде духовен водач и св. Иван Рилски е именно такъв. Но отново ще повторя - не искам да бъда съдник на П. Мутафчиев: неговата позиция (макар и неприемлива) може да бъде разбрана. Той упорито търси в българската история водители, способни да събудят позитивните енергии на българския народ. Отшелничеството загърбва според него държавническия и социален императив, затова и рилският светец е оценен негативно.

Критика идва и от лагера на адептите на богомилството, разбирано като оригинална философско-антропологична, етична и социална доктрина, повлияла на средновековните западноевропейски хетеродокси. Според тази концепция есето е израз на „българското отрицателство“, а П. Мутафчиев, подобно на други автори от епохата, задава една матрица, която именно с негативистко-мизантропичните си тенденции охотно бива възприемана от родния ни културен мазохизъм, за който последно убежище в социално-политическите бури е обругаването на българскотоㄹ.

Поп Богомил и Свети Иван Рилски е особен текст, който не може да бъде разбран без полагането му в контекста на европейския и българския духовен климат между двете световни войни. Личат навеи от неизживените напълно от автора социалистически увлечения. Честото повтаряне на фрази като народ, народни маси, исторически създаден колективитет в опозиция на пасивна съпротива на народа срещу наложената от държавата нова религия, ретроградна Православна църква и др. отвеждат към една по-скоро социалистическа, но не и вулгарно-марксистка интерпретация на ереста. Тези фрази обаче могат да бъдат интерпретирани и в посока на десни европейски идеологически проекти, доколкото италианският фашизъм и националсоциализмът са десни идеологии. Известен факт е, че за един определен период Б. Кроче - безспорен авторитет за П. Мутафчиев - е бил верен последовател на Мусолини. Племенният дух, родната земя, народните маси, виталността на езичеството в опозиция на изживяното християнство, копненията по силния водач - това са все клишета, натоварени с негативни конотации и заклеймени като фашистки от предишната, а и от новата левица, за които всеки опит за разграничаване от радикалното ляво е не просто дясно, но и фашистко, расистко и т.н. Но както Б. Кроче, така, струва

1 Статия на Стефан Чурешки онлайн (Chureshki pre-2004).

2 Lazarova 2010: 55 . 
ми се, и П. Мутафчиев трудно се вмества в калъпите на идеологически схеми. След 1926 г. италианският философ преодолява ранните си политически увлечения и от поддръжник на Мусолини се превръща в идеолог на либерално настроената италианска интелигенция и противник на режима. Термините народ, религия, философски историзъм се схващат в морално-етически план, а самата история е история на моралния и граждански живот ${ }^{1}$. Не е излишно да се добави, че тези възгледи не бива да се разглеждат откъснато от историческите съчинения на Б. Кроче, посветени на обединението на Италия. Вглеждайки се по-внимателно в историософските прозрения не П. Мутафчиев, ще открием същия морално-етически императив, наложен върху разсъжденията му за българската история. Идеологическите калъпи на ляво, дясно, фашистко не работят, когато се прилагат към изтъкнати индивидуалности, каквито са били както италианският философ, така и българският историк.

Въпреки това някои от тях охотно се използват от левицата, по-стара и по-нова. Неслучайно по-късни коментатори на научното творчество на П. Мутафчиев от комунистическо време разглеждат неговите възгледи и в частност неговото тълкуване на богомилството като проява на ретроградни, националистически, фашистки или вулгарно-материалистически възгледи. В научния донос срещу историка от 50-те години на XX в. той е субективен идеалист, преувеличил ролята на личността в историята, буржоазен националист и великобългарски шовинист, а отношението му към ереста било непоследователно: богомилите били ту проповедници на пораженството, ту идейни подбудители на движения за национално освобождение и държавна независимост².

Вулгарно-материалистически стават възгледите на П. Мутафчиев по-късно, през 8о-те години на XX в., когато, за да се издадат трудовете му, е необходимо да се припомнят ранните му увлечения по социализма и да се изтъкне неговото положително отношение към народните маси, пък било то и от позициите на вулгарния материализъм. Еднопланова трактовка, подчинена на политическата конюнктура.

Истинските корени на философските и социални възрения на автора би трябвало да се търсят, както отбелязах по-горе, в неохегелианската концепция на Бенедето Кроче за абсолютния историзъм, в антипозитивистичната нагласа на европейските интелектуалци, следствие на травмираното обществено съзнание след ужасите на

1 Croce 1951: 110-127.

2 Текстът на П. Петров Буржоазно-идеалистическите и реакционно-фашистките възгледи на проф. Петър Мутафчиев от Исторически преглед (Petrov 1951). Цит. по: Mutafchiev 1993: 339-370. 
една световна война и мрачните предчувствия за нов апокалипсис. Именно тези нагласи, положени върху текстове и личности от българската история, оставят може би усещане за негативизъм и песимизъм след прочита на есето. Струват ми се неудачни опитите да се търсят паралели (дори типологически) между Поп Богомил и Св. Иван Рилски и един друг емблематичен текст за епохата - статията на Найден Шейтанов Духът на отрицание у българина, публикувана една година преди есето на П. Мутафчиев ${ }^{1}$. Н. Шейтанов е фройдист и етнолог, гради народопсихологическите си разсъждения на базата предимно на фолклорен материал. Наблюденията на П. Мутафчиев ca sensu stricto исторически, като повечето от историософските му идеи се формират много по-рано (вж. напр. встъпителната лекция от 1923 г.), което не пречи на критиците му да го обвиняват в скрито плагиатство (!): Всъщност, той (П. Мутафчиев - Г. М.) тук следва, но без да ццитира зададения от Н. Шейтанов през 1933 г. еталон за „духа на отрицанието у българина”, показвайки устойчивостта на една продължаваща във времето тенденция на скрито плагиатство, към която научната област у нас е неоправдано толерантна! ${ }^{2}$.

Вече се опитах да докажа, че песимизмът е атмосфера, белязала духовните търсения на голяма част от българската междувоенна интелигенция. В този смисъл песимизмът на П. Мутафчиев е визионерски, той е предусетил една бъдеща национална катастрофа и е проектирал страховете си в далечното минало. Някои от неговите идеи будят възражения и се нуждаят според мен от корекция: естествено е за читателя на едно приносно съчинение да търси диалог с автора - в съгласие или не с неговите възгледи. Фактът, че оригиналната концепция на П. Мутафчиев стои встрани от отъпканите пътеки на предшестващи я възгледи и дразни по-късни интерпретатори на богомилския мит, свидетелства само в полза както на есето, така и на цялостната визия на българския историк за богомилската ерес.

Не бива да забравяме и за антиклерикалните настроения, общи за по-голямата част от българската междувоенна интелигенция (независимо от политическите ѝ пристрастия), които не са подминали и университетските преподаватели. В случая Петър Мутафчиев обаче трябва да бъдем по-внимателни. Негативното му отношение към официалната Църква не е следствие на марксистки догми или увлечения по езотерични доктрини. Във философските есета и академичната си историографска продукция той търси политически и духовни водачи, примери за обществото (или за народа, ако използваме неговата терминология). Не ги намира в миналото, където

1 Публикувана във Философски преглед (Sheytanov 1933).

2 Lazarova 2010: 55 (бел. 13). 
църковната йерархия не изпълнявала според него пастирските си задължения, оставяйки паството в невежество и в ръцете на съмнителни религиозни лидери като богомилите. И в това отново виждам визионерския песимизъм на П. Мутафчиев, приложим не само към случващото се в България преди и по време на II световна война, но и след това, та чак до наши дни...

Ако трябва да търсим корените на негативното отношение към византинизма и богомилството в творчеството на П. Мутафчиев, ще трябва да се обърнем и към неизживените възрожденски идеали на част от българската интелигенция между двете войни. П. Мутафчиев не е просто отрицател на външни влияния в българския духовен живот и това ясно личи във встъпителната лекция от 1923 г., където дава достатъчно примери за значението на Средновековието за духовното развитие на цяла Европа. Едновременно с това той, подобно на други историци от епохата (напр. В. Златарски), оценява негативно влиянието на Византия, разбирано като гръцко влияние и схващано като пагубно за народността още от отец Паисий Хилендарски. Можем да се съгласим или не с подобна концепция, но тя е жива сред онази част от българското общество, която във време на политически и духовни сътресения търси потенциал за преодоляването им в родното: народ, език, държавност, народни водачи. Рушителите на държавност и вяра не могат да предизвикат симпатиите на автора. В този смисъл бих разбрал, без да съм съгласен с него, и негативното му отношение към анахоретството като проява на византинизма. Но така или иначе - Петър Мутафчиев не е обругаващ българското мизантроп, обратно - той търси именно в българското образци за духовен и политически подем. И тъй като е честен към областта на знанието, с която професионално се занимава, рядко намира тези образци в родната история. Оттам идва и песимизмът му.

\section{REFERENCES}

Angelov 1969: Angelov, Dimitar. Bogomilism in Bulgaria. Sofia: Nauka i izkustvo, 1969. [In Bulgarian: Ангелов, Димитър. Богомилството в България. София: Наука и изкуство, 1969.]

Blagoev 1906: Blagoev, Dimitar. Contribution to the History of Socialism in Bulgaria. Sofia: Socialist Party Bookstore, 1906. [In Bulgarian: Благоев, Димитър. Принос към историята на социализма в България. София: Партийна социалистическа книжарница, 1906.]

Chureshki (pre-2004): Chureshki, Stefan. "The Revival of Paganism and Heresies in Bulgaria Follows the Path of Science." Pravoslavieto.com. The Bulgarian Orthodox Catalog on the Internet. http://www.pravoslavieto.com/inoverie/vazobn_ezichestvoto_chureshki.htm (access: o6. o6. 2020). [In Bulgarian: Чурешки, Стефан. „Възобновяването на езичеството и ересите в България върви 
по пътя на науката.“ Pravoslavieto.com. Българският православен каталог в Интернет. http://www.pravoslavieto.com/inoverie/vazobn_ezichestvoto_chureshki.htm.]

Croce 1951: Croce, Benedetto. "Intorno alla filosofia della storia." In Croce, B. I primi saggi. Bari: Gius. Laterza \& Figli, 1951.

Elenkov 1998: Elenkov, Ivan. Native and Right. Contribution to the History on the Unrealized 'Right Project' in Bulgaria during the Period between the Two World Wars. Sofia: Lik, 1998. [In Bulgarian: Еленков, Иван. Родно и дясно. Принос към историята на несбъднатия „десен проект“ в България от времето между двете световни войни. София: Лик, 1998.]

Gyuzelev 1987: Gyuzelev, Vasil. "The Reflections of Prof. Petar Mutafchiev on the Bulgarian Medieval History." In Mutafchiev, Petar. Book on the Bulgarians, 5-21. Sofia: BAS, 1987. [In Bulgarian: Гюзелев, Васил. "Размишленията върху българската средновековна история на проф. Петър Мутафчиев." В: Мутафчиев, Петър. Книга за българите, 5-21. София: БАН, 1987.]

Iliev 2002: Iliev, Ilia. "The Reign of Prince Rasate (Vladimir) (889-893). An Unsuccessful Attempt for European Reorientation in Bulgaria's Foreign Policy." In Gyuzelev, V. \& Miltenova, A., eds. Medieval Christian Europe: East and West, 407-410. Sofia: Gutenberg, 2002. [In Bulgarian: Илиев, Илия. „Управлението на княз Расате (Владимир) (889-893). Един неуспешен опит за европейска преориентация във външната политика на България.“ В: Гюзелев, В. \& Милтенова, А., ред. Средновековна християнска Европа: Изток и Запад. Ценности, традиции, общуване, 407-410. София: Гутенберг, 2002.]

Ivanov 2019: Ivanov, Yordan. Bogomil Books and Legends. Sofia, 1925; 3rd ed.: Sofia: Shambala, 2019. [In Bulgarian: Иванов, Й. Богомилски книги и легенди. София, 1925; 3. изд.: София: Шамбала, 2019.]

Kiossev 1999: Kiossev, Alexander. “The Self-Colonizing Metaphor.” In: Elenkov, I., ed. New Publicity. Bulgarian Debates. Sofia: Open Society Foundation, 1999. Original publication in English in: Ginev, D., Sejersted, F. \& Simeonova, K., eds. Cultural Aspects of the Modernisation Process. Oslo: TMV-senteret, 1995. [In Bulgarian: Кьосев, Александър. „Бележки за само-колонизиращите се култури.“ В: Еленков, И., съст. Нова публичност. Българските дебати. София: Отворено общество, 1999.]

Klincharov 2019: Klincharov, Ivan. Priest Bogomil and His Times. Sofia, 1927. 3rd ed.: Sofia: Shambala, 2019. [In Bulgarian: Клинчаров, Иван. Поп Богомил и неговото време. София, 1927. 3. изд.: София: Шамбала, 2019.]

Krastev 1927: Krastev, Kiril. “The Possibilities for a Bulgarian Culture.” Strelets, no 7 (18.05.1927): 1. [In Bulgarian: Кръстев, Кирил. „Възможностите за една българска култура.“ Стрелец, бр. 7 (18.05.1927): 1.]

Lazarova 2010: Lazarova, Erika. "Bogomilism between Myths and Ideologies." In Annual of Regional History Museum - Plovdiv (National Scholarly Conference "Myths and Histories in Bulgaria"), book 7 (2010): 52-61. [In Bulgarian: Лазарова, Ерика. „Богомилството между митовете и идеологемите." Годишник на Регионален исторически музей - Пловдив (Национална научна конференция „Митове и истории в България“), кн. 7 (2010): 52-61.]

Mutafchiev 1931: Mutafchiev, Petar. “Towards the Philosophy of Bulgarian History. Byzantinism in Medieval Bulgaria." Filosofski Pregled, book 1 (1931): 27-36. Cited according to Mutafchiev 1993: 159-168. [In Bulgarian: Мутафчиев, Петър. „Към философията на българската история. Византинизмът в средновековна България." Философски преглед, кн. 1 (1931): 27-36. Цит. по: Mutafchiev 1993: 159-168.] 
Mutafchiev 1934: Mutafchiev, Petar. "The Priest Bogomil and St. John of Rila. The Spirit of Negation in Our History." Filosofski Pregled, book 2 (1934): 1-16. Cited according to Mutafchiev 1993: 169-184. [In Bulgarian: Мутафчиев, Петър. „Поп Богомил и Свети Иван Рилски. Духът на отрицанието в нашата история.“ Философски преглед, кн. 2 (1934): 1-16. Цит. по: Mutafchiev 1993: 169-184.]

Mutafchiev 1986: Mutafchiev, Petar. A History of the Bulgarian Peoples 681-1323. 2nd ed. Sofia: BAS, 1986. [In Bulgarian: Мутафчиев, Петър. История на българския народ 681-1323. 2. изд. София: БАН, 1986.]

Mutafchiev 1987: Mutafchiev, Petar. Book on the Bulgarians. Sofia: BAS, 1987. [In Bulgarian: Мутафчиев, Петър. Книга за българите. София: БАН, 1987.]

Mutafchiev 1993: Mutafchiev, Petar. East and West in the European Middle Ages. Sofia: BAS, 1993. [In Bulgarian: Мутафчиев, Петър. Изток и Запад в европейското средновековие. София: БАН, 1993.]

Pampov 2013: Pampov, Kostadin. Philosophy of Medieval Bulgarian History. The View of Prof. Petar Mutafchiev. Pazardzhik: Belloprint, 2013. [In Bulgarian: Пампов, Костадин. Философия на средновековната българска история. Гледната точка на проф. Петър Мутафчиев. Пазарджик: Беллопринт, 2013.]

Petrov 1951: Petrov, Petar. "The Bourgeois-Idealist and Reactionary-Fascist Views of Prof. Petar Mutafchiev." Istoricheski Pregled, book 4-5 (1950/1951): 393-425. Cited according to Mutafchiev 1993: 339-370. [In Bulgarian: Петров, Петър. „Буржоазно-идеалистическите и реакционнофашистките възгледи на проф. Петър Мутафчиев." Исторически преглед, кн. 4-5 (1950/1951): 393-425. Цит. по: Mutafchiev 1993: 339-370.]

Racki 1931: Rački, Franjo. “Bogomili i patareni.” In Rački, F. Borba južnih Slovena za državnu neodvisnost. Bogomili i patareni. 2nd ed. Beograd: Srpska kraljevska akademija, 1931. Original ed. in Rad Jugoslavenske akademije znanosti i umjetnosti, books 7 \& 8 (1869), book 10 (1870).

Rikev 2020: Rikev, Kamen. Because It Is Hidden... The Christian Worldview in the Works of Atanas Dalchev. Lublin: UMCS, 2020. [In Bulgarian: Рикев, Камен. Защото е на скрито... Християнският светоглед в творчеството на Атанас Далчев. Lublin: UMCS, 2020.]

Sheytanov 1933: Sheytanov, Nayden. "The Spirit of Negation in the Bulgarian." Filosofski Pregled, book 2 (1933): 128-141. [In Bulgarian: Шейтанов Найден. „Духът на отрицание у българина.“ Философски преглед, кн. 2 (1933): 128-141.]

Stefan 2012: Exarch Stefan. Bogomils and Cosmas the Presbyter. Sofia: Iztok-Zapad, 2012. [In Bulgarian: Екзарх Стефан. Богомилите и Презвитер Козма. София: Изток-Запад, 2012.]

Szwat-Gylybowa 2010: Szwat-Gylybowa, Grazyna. Bogomilism: The Afterlife of the „Bulgarian Heresy”. English translation: Warsaw: Institute of Slavic Studies, Polish Academy of Sciences, 2017. Transl. by P. Szymczak. [Original ed. in Polish: Szwat-Gyłybowa, Grażyna. Haeresis bulgarica w bułgarskiej świadomości kulturowej XIX i XX wieku. Warszawa: SOW, 2005; in Bulgarian: Шват-Гълъбова, Гражина. Haeresis bulgarica в българското културно съзнание на XIX и XX век. София: УИ Св. Климент Охридски, 2010. Прев. В. Деянова и Г. Коминек.]

Topencharov 1974: Topencharov, Vladimir. Two Embers. One Flame. Bougres and Cathars: Why the First Pan-European Popular Wave Against Feudalism Was Called "the Bulgarian Heresy”. Sofia: Nauka i Izkustvo, 1974. [In Bulgarian: Топенчаров, Владимир. Две жкарави. Един пламък. Бугри и катари: Защо първата общоевропейска народна вълна против феодализма бе наречена „българска ерес". София: Наука и изкуство, 1974.] 